\title{
РАЗВИТИЕ ФОРМ УЧАСТИЯ НАСЕЛЕНИЯ В РЕШЕНИИ ВОПРОСОВ МЕСТНОГО ЗНАЧЕНИЯ: РЕТРОСПЕКТИВНЫЙ АНАЛИЗ
}

В статье представлен анализ современных и сформированных в прошлом тенденций относительно участия населения в решении вопросов местного значения. Рассматривается сущность и особенности территориальной общины как субъекта местного самоуправления согласно украинскому законодательству, выделены основные содержательные аспекты местного самоуправления применительно к данному исследованию.

Анализ эволюции общественных трансформаций на уровне местного самоуправления позволил сделать вывод о том, что идеи и практика самоуправления имели место ещё в глубокой древности (до возникновения государственности), преимущественной формой которого были народные собрания и советы старейшин, получившие в дальнейшем статус постоянных органов управления. Рассматриваются особенности вечевой демократии на территории Украины. Показаны специфические черты веча как важного института развития местного самоуправления, ставшего одним из органов государства, власть которого реализовывалась путём собрания полноправных граждан старшего города земли при участии населения предместий. Показаны особенности созыва, проведения веча и принятия решений.

Выделены причины быстрого распространения магдебургского права на территории Украины. Проведён хронологический анализ получения магдебургского права украинскими городами, что позволило выделить три категории таких городов, а также разделить такие города в зависимости от их статуса. Представлены особенности самоуправления населения городов на магдебургском праве, в частности структура органов местной власти, процедура местных выборов, проблемы в осуществлении на украинской территории.

Проведённый в статье анализ позволил сделать вывод о формировании института участия членов территориальной общины в структуре местного самоуправления в решении вопросов местного значения как определённой системы, которая является совокупностью организационных форм и институтов прямого самоуправления, с помощью которых реализуются принципы и функции местного самоуправления.

Ключевые слова: местное самоуправление, исторический анализ, власть, органы управления, вече, магдебургское право, участие жителей.

\section{1. ВВЕДЕНИЕ}

В условиях усовершенствования осуществления публичной власти в Украине появилась чрезвычайно сложная проблема реформирования местного управления,

\footnotetext{
${ }^{1}$ Людмила Муркович магистр по государственному управлению, соискатель кафедры государственного управления и местного самоуправления Днепропетровского регионального института государственного управления Национальной академии государственного управления при Президенте Украины, электронная почта: albina19murkovich @ gmail.com
} 
совершенствования форм и методов его осуществления. Принимая во внимание это, развитие института местного самоуправления является важным шагом в дальнейшей демократизации общественной жизни. Важность этого процесса обусловлена и тем, что само местное самоуправление выступает в качестве важной составляющей механизма реализации прав человека на местном уровне.

Недостаточное освещение теоретических и прикладных аспектов участия территориальных общин и образованных ими органов самоорганизации населения в решении вопросов местного значения в науке государственного управления предопределяет важность разработки новых концептуальных подходов относительно усовершенствования форм непосредственной демократии на местном уровне. Важным также является разработка новых механизмов реализации права граждан на местное самоуправление с целью налаживания системного публичного диалога между властью и населением.

Конституционное закрепление за территориальной общиной статуса первичного субъекта местного самоуправления значит, что её члены также являются участниками управленческого процесса на локальном уровне. Современный этап развития местной демократии в Украине характеризуется повышением роли членов территориального общества в процессе принятия органами местного самоуправления управленческих решений. Местные советы пытаются налаживать сотрудничество с членами территориальных общин, привлекать их к общим мероприятиям с целью решения неотложных проблем. Дальнейшее развитие партнёрства органов местного самоуправления с населением должно стать залогом решения наиболее актуальных вопросов, которые волнуют жителей.

В исследовании обеспечения развития форм участия территориального общества в решении вопросов местного значения особое значение приобретает научнотеоретическое определениеи характеристика тех понятий, которые составляют непосредственное предметное поле данного исследования. Предоставление сущностной характеристики основных понятий требует проведения эмпирического, элементарно-теоретического и исторического анализа, который позволит выделить характерные качества исследуемого явления.

\section{2. ЭВОЛЮЦИЯ ФОРМИРОВАНИЯ МЕСТНОЙ НЕПОСРЕДСТВЕННОЙ ДЕМОКРАТИИ НА ТЕРРИТОРИИ УКРАИНЫ}

В соответствии со ст. 140 Конституции Украины и ст. 3 Закона Украины «О местном самоуправлении в Украине» граждане, которые относятся к соответствующим территориальным общинам, имеют право реализовывать право на участие в осуществлении местного самоуправления как непосредственно, так и через сельские, поселковые, городские советы и их исполнительные органы, а также через районные и областные советы, которые представляют общие интересы территориальных общин сел, поселков, городов ${ }^{2}$.

Поскольку понятие «местное самоуправление» отображает комплексное и разнообразное явление, то его реализация порождает различные подходы к исследованию участия членов территориального общества в решении вопросов

\footnotetext{
${ }^{2}$ Конституція України : прийнята на п’ятій сесії Верховної Ради України 28 черв. 1996 р. - Режим доступу : http://zakon4.rada.gov.ua/laws/show/254\%D0\%BA/96-\%D0\%B2\%D1\%80., C.9.
} 
местного значения. В пределах данного предметного поля следует выделить такие содержательные аспекты местного самоуправления:

- право территориальной общины, как населения соответствующей территории, на самостоятельное разрешение местных дел (это предусматривает со стороны государства признание автономности местного самоуправления, его самостоятельности в пределах определённых законом, а также обязательство государства относительно создания необходимых условий для его осуществления, обеспечения судебной защитой и другими гарантиями);

- формы и способы осуществления территориальной общиной власти на местном уровне, кторые обеспечивают самостоятельное решение гражданами вопросов местной жизни с учётом исторических и других местных традиций.

Одной из основных функций местного самоуправления является обеспечение участия населения в решении местных вопросов. Местное самоуправление способствует приближению власти к народу, созданию гибкого механизма местного управления с меньшей бюрократией, чем при централизованной системе управления. Это предусматривает развитие непосредственной демократии, создание условий для самостоятельного решения населением дел местного значения, поддержку инициатив и самодеятельности граждан, разных форм самоуправления.

Эволюция общественных трансформаций свидетельствует о том, что во все времена люди самоорганизовывались и объединялись в разные коллективы для самостоятельного решения своих неотложных проблем, обеспечения собственной жизнедеятельности и интересов. Общественное самоуправление было и является проявлением активности граждан, формы коллективного объединения людей, с помощью которых они добровольно и безвозмездно участвуют в разрешении конкретных дел местных сообществ. Оно является системой управления общественными делами, построенной на основе самоорганизации, самодеятельности

и саморегулирования. Общественное самоуправление - это одна из разновидностей и производных народовластия, и в то же время важный фактор его становления и развития.

Мировое сообщество сегодня в целом формулирует основные требования к осуществлению местного самоуправления, которые отвечают базовым признакам демократических государств, наработанные в течение многих веков. Такие страны и их административно-территориальные единицы должны были решать вопрос относительно того, допускать ли народ, как неосведомлённую массу, к управлению или избрать вариант, когда все проблемы на местном уровне должны разрешать избранные населением компетентные должностные лица. История доказала, что наиболее эффективным является не прибегать к крайностям, а выработать такую модель местного самоуправления, когда определяется степень участия населения, разрабатываются механизмы и формы взаимодействия власти и населения ${ }^{3}$. На каждом этапе исторического развития изменялся характер и масштабы местного самоуправления. Определённые объективные и субъективные причины функционирования народовластия содействовали росту политического сознания и

\footnotetext{
3 Заборова Е. Н. Участие граждан в управлении городом / Е. Н. Заборова // Социс. - 2002. - № 2. - С. 23 - 24.
} 
политической культуре населения и как следствие - имели продуктивное влияние на улучшение общинного самоуправления.

Исторический опыт разных эпох и народов свидетельствует о том, что идеи и практика самоуправления восходят к глубокой древности, фактически начиная с первобытнообщинного строя. Они обеспечивали существование разных сообществ на принципах самоорганизации, развивались и обогащались, приобретая все более сложные формы на следующих ступенях исторического прогресса: от родоплеменного уклада, в котором управление осуществлялось на основе принципа первобытной демократии, к сложной организационной структуре управления государством. Такую связь можно проследить на примере эволюции народных собраний и советов старейшин, которые получили в дальнейшем статус постоянных органов управления (народных собраний «панку» у хетхов; китайских собраний свободных граждан «гожень»; индийских народных собраний «сабха» или «самити»; военных сходок индейцев Северной Америки; афинских народных собраний; римских комиций; народных собраний древних германцев; скандинавских «тингов»; древнерусского веча 4 .

Местное самоуправление в Украине также имеет давнюю историю. Как и многие другие общественно-политические институты нашей страны, оно развивалось достаточно самобытно и не равномерно, его результаты не всегда и не во всем совпадали со становлением этого явления в других странах. Однако, резкое противопоставление отечественного опыта зарубежному не является верным, потому что принципы гражданской активности населения, которые были реализованы в демократических государствах и Украине по содержанию похожи, особенно учитывая европейское влияния на осуществление отечественного городского самоуправления.

Среди важнейших особенностей украинского исторического пути следует выделить то, что страна на протяжении веков развивалась в достаточно сложной геополитической обстановке, была объектом многовековой агрессии сначала со стороны кочевых народов, а потом других стран, что отразилось на эволюции государства и условиях развития местного самоуправления. Невзирая на это, отечественные традиции местного самоуправления имеют глубокие корни, что обусловлено объективными историческими причинами.

Наиболее значимыми вехами формирования местной непосредственной демократии в Украине следует назвать самоуправление на Руси в виде вечевой демократии, а также введение и действие норм магдебургского права.

\section{3. ВЕЧЕВАЯ ДЕМОКРАТИЯ КАК ФОРМА УЧАСТИЯ НАСЕЛЕНИЯ В РЕШЕНИИ ВОПРОСОВ МЕСТНОГО ЗНАЧЕНИЯ}

Уже в начале становления Киевского государства определились общие черты местного самоуправления, его основные формы, признаки и некоторые параметры взаимодействия с центральной властью; непосредственное участие народа в местном самоуправлении; выборность должностных лиц; зависимость от центральной власти и подчинение ей по определённому кругу вопросов;

\footnotetext{
${ }^{4}$ Коваленко Н. Е. Местное самоуправление как форма демократии: учеб. пособие / Н. Е. Коваленко. СПб. : изд-во СПбГУЭФ, 2008. - С.55-56.
} 
самостоятельность в решении заданий местного значения. Развитию самоуправления содействовал тот факт, что княжеская власть имела ограниченную возможность поставить под контроль децентрализованную земледельческую периферию, а рассеивание на большой территории небольших сел делало возможным осуществление преимущественно фискальной функции.

На Руси важнейшей особенностью городского самоуправления был его вечевой характер («вече» от старославянского «вет» - совет). Его происхождение имеет догосударственный характер. Как отмечал М. Грушевский, вече было элементом и давним (исходя из племенного самоуправления), и новым (приобрело новую политическую окраску под воздействием княжеско-дружинного уклада $)^{5}$. C доисторическим происхождением веча (до IX века) соглашается М. ВладимирскийБуданов, давая его определение во времена Киевской Руси как органа государственной власти, которая реализуется путём собрания полноправных граждан старшего города земли ${ }^{6}$.

Таким образом, государственное управление характеризовалось определённым дуализмом, когда одновременно существовала княжеская власть и вече. При этом граждане не относились враждебно к государству и князю, вечевой уклад позволял им свободно относиться к князю, как выразителю народной воли. Верховенство и первенство князя зависели от его индивидуальных способностей и качеств. Если народ был недоволен князем, то мог с помощью вечевого порядка призвать на княжеский престол того, кто не только имел родовое право его занять, но и казался самым идеальным правителем. Вече заключало с претендентом договор относительно управления государством, а при нарушении его условий - устраняло такого князя7. Возможно, именно с такими событиями связывают тот факт, что наибольшее развитие на территории Украины приобрело киевское вече, в других городах его деятельность была не такой значительной ${ }^{8}$.

Вече состояло из всех полноправных совершеннолетних граждан старшего города, участие жителей предместья также было возможным, потому что сохранялась идея всенародного участия в таких собраниях. В то же время, она практически не была реализована из-за того, что фактически собрать всех жителей большой территории в одном месте было невозможным, потому такое участие было случайным. Решения веча главного города были обязательными для предместья и сел ${ }^{9}$, которые составляли волость, поскольку их жители считали себя младшими относительно горожан. Сельская территориальная община в XI - XII веков (мир, задруга, вервь) сочетала в себе элементы соседского и семейного сообщества, которое занималось вопросами перераспределения земельных наделов,

\footnotetext{
${ }_{5}^{5}$ Грушевський М. Історія України-Русі: в 11 т. / М. Грушевський. - К. : Наукова думка, 1991. - Т. 3. C.209.

${ }^{6}$ Владимирский-Буданов М.Ф. Обзор истории русского права / М. В. Владимирский-Буданов. - Ростов-наДону: Феникс, 1995. - С.74-75.

${ }^{7}$ Т исяча років vкраїнської сvспільно-політичної дvмки; у 9 т. Т. 1 / упоряд. О. Сліпушко; редкол. Т. Гунчак [та ін.]. - К.: Дніпро, 2001. - С. 175-176.

${ }^{8}$ Грушевський М. Історія України-Русі: в 11 т. / М. Грушевський. - К. : Наукова думка, 1991. - Т. 3. C.210.

9 Чубатий М. Огляд історії українського права. Історія джерел та державного права : у 2 ч. Ч. 1 Мюнхен: [б.в.], 1947. - С.71.
} 
решением фискальных вопросов, ведением судебных тяжб и споров, расследованием преступлений и осуществлением наказаний. Именно для решения вопросов местного управления, как правило, могло собираться вече в предместье.

Если вече собиралось не для устранения и приглашения нового князя путём созыва звоном или криками, то сам князь мог его созывать и участвовать в нем вместе с боярской думой и духовными лицами. Решения принимались фактически подавляющим большинством голосов. Таким образом, вече не было органом одного (простонародного) класса и представляло власть общеземскую. В течение XI - XII веков влияние веча было значительным, принимая во внимание широту его прав в различных сферах: вечевого законодательства; внешней политики и мира; государственного строя (приглашение и смещение князей); судебной власти; текущего управления (замещение чиновников) $)^{10}$. Как отмечал Я. Падох, этот ранний демократизм был очень глубоким и сильным, органично связанным с мировоззрением украинского человека ${ }^{11}$.

В XII - начале XIII веков местная власть сосредоточилась исключительно в руках князей, которые передавали свои властные полномочия и должность по наследству. В этих условиях на большинстве территорий древнерусского государства объем прав и полномочий органов местного самоуправления был перераспределён в пользу князя и его жены. Права веча существенно ограничивались, особенно при сильном князе и, наоборот, возрастали при слабом.

В связи с монголо-татарским нашествием старшие города утратили своё былое значение и практически ослабели, что привело к исчезновению такой формы местной демократии как вече. Общины потеряли свою роль самоуправных единиц, поскольку территории были экономически и политически парализованы. Этим самым в значительной степени была деформированна основа общества, которая представляла сословно-представительскую власть, концентрирующаяся главным образом в политико-экономических центрах территорий.

Общинно-вечевой строй Киевской Руси, который стал результатом эволюции давних начал жизни славянских племён, соответствовал таким же тенденциям развития и других европейских народов. Сформированное в результате городское управление было близким к европейскому, что способствовало быстрому распространению магдебургского права на территории Украины. Другими факторами его распространения была немецкая колонизация восточноевропейских стран XII - XV веков, в том числе и Украины; соответствие норм магдебургского права социальным и экономическим потребностям украинских городов, что позволило адаптировать один из вариантов немецкого городского права на отечественной почве; близость украинцев к европейской культуре.

\section{4. РЕЦЕПЦИЯ МАГДЕБУРГСКОГО ПРАВА НА ТЕРРИТОРИИ УКРАИНЫ}

Распространение магдебургского права в украинских городах была мирной, в отличие от получения коммунальных свобод городами стран Западной Европы. В

\footnotetext{
${ }^{10}$ Владимирский-Буданов М. Ф. Обзор истории русского права / М. В. Владимирский-Буданов.- Ростов-наДону: Феникс, 1995. - С.81-82.

${ }^{11}$ Т исяча років vкраїнської сvспільно-політичної пvмки; у 9 т. Т. 1 / упоряд. О. Сліпушко; редкол. Т. Гунчак [та ін.]. - К.: Дніпро, 2001. - С.175-176.
} 
городах, которые входили в состав Галицко-Волынского государства, а потом со средины XIV ст. Польского королевства, Великого княжества Литовского, Речи Посполитой, юридическое воплощение магдебургского права осуществлялось в результате усилий государственной власти и владельцев городов через заключение магдебургских грамот и других актов ${ }^{12}$.

В научной литературе из-за недостаточности исторических источников отсутствует единая точка зрения относительно хронологии получения магдебургского права украинскими городами. Некоторые документы удостоверяют, что ещё во времена Галицко-Волынского княжества некоторые украинские города имели частичное магдебургское право. Одними из первых городов на этнических западно-украинских землях, которые получили привилегию на самоуправление по немецкому праву, были города Новый Сонч (1229/1294г.), Львов (1287 г.), Владимир (1324 г.), Луцк (1287 г. $)^{13}$. Наличие грамоты о предоставлении магдебургского права городу Сянок в 1339 г. засвидетельствовало беспрекословно этот факт, но не стало подтверждением первенства этого города в получении такого права.

Исследователи насчитывают до 400 городов, городков и сел, которым в течение XIV - XVI веков было предоставлено самоуправление на немецком праве. Достаточно рано получили такое право города Закарпатья, которые входили в состав Венгрии (Хуст, Вышков, Тячив - с 1329 г.). Первой исторической датой, которая указывает на рецепцию немецкого права на восточно-украинских землях, является привилегия на магдебургию для Каменец-Подольского, предоставленная во времена Великого Княжества Литовского (в 1374 г.). Значительно более интенсивно немецкое право стало распространяться в центральной и восточной частях Украины с XV века (Кременец, Житомир, Киев, Ковель, Переяслав, Чигирин, Канев). Другим городам (Стародубу, Нежину, Чернигову) оно было предоставлено только в первой половине XVII века.

Хронологический анализ позволяет все города магдебургского права в Украине разделить на три категории. К первой относятся города преимущественно Правобережной Украины, которые получили такое право от литовских князей, польских и венгерских королей. Во вторую категорию входили города, которые получили привилегию на устройство по немецкому праву от их владельцев (например, города Лохвица, Лубны, Пирятин, Прилуки получили его в XVI ст. от князей Вишневецких), которое могло быть изменено или отменено. К третьей категории принадлежали города, которым магдебургское право было дано грамотами гетманов после присоединения Украины к Московскому государству (в 1752 г. Полтаве такое право было подарено гетманом К. Разумовским). До конца XVIII века магдебургское право получили почти все города Левобережной Украины. Грамоты гетманов преимущественно подтверждали права городов Украины на самоуправление, которое они получили, находясь ещё под литовским и польским господством.

\footnotetext{
${ }^{12}$ Грушевський М. Історія України-Русі: в 11 т. / М. Грушевський. - К. : Наукова думка, 1991. - Т. 5. C.225, 227, 11 . ${ }^{13}$ Яремчук В. Бондарчук Я. Магдебурзьке право в Острозі: європейські традиції в українському. - Режим
доступу: http://www.day.kiev.ua/27245/. - Назва з екрану.- С.120.
} 
Исходя из статуса, учёные выделяют две группы магдебургских городов: города с полным магдебургским правом - магистратские города (Львов, Каменец, Киев), где формировались городские представительские органы власти - совет с бургомистром и лава с войтом, что составляли магистрат; города с полным магдебургским правом - ратушные города (все остальные).

Города с магдебургским правом получали самоуправление, что (как отмечено в магдебургской грамоте Львова) значило исключение его из-под юрисдикции всех административных и судебных органов государства, его общего законодательства и передачу под руководство войта ${ }^{14}$. Магдебургское право регламентировало порядок избрания городской власти, её функции, основные нормы гражданского и уголовного права, правила судопроизводства и налогообложения, определяло деятельность купеческих объединений, ремесленных цехов, порядок торговли и тому подобное.

Получение городами права самоуправления превращало их жителей в замкнутое, корпоративное сообщество. Мещанство выделилось в отдельную общественную группу, которая имела свои сословные органы самоуправления. Таким органом в крупных городах был выборный городской совет (магистрат), который, как правило, состоял из войта (возглавляющего магистрат), его помощников (бургомистров) и двух коллегий - совета (членов магистрата, ратманов, советников) и лавы (лавников, заседателей). Магистрат избирался городским населением (иногда войт назначался государственной властью). Количество членов магистрата в зависимости от размера города колебалось от 6 до 24 лиц. Из своего состава члены магистрата избирали бургомистра, который председательствовал на заседании совета.

Выборы осуществлялись ежегодно в заранее определённый день. В выборах участвовали все мещане города. Для членов городского самоуправления в разных городах устанавливался возрастной ценз - от 25 до 70 лет. Требования к кандидатам в органы городского самоуправления касались зажиточности («из мещан знатных..., не излишне богатых... и не очень скудных»), осёдлости («дома всегда жить»), личных качеств («постоянных, совестливых, рассудительных, добронравных и где могут быть учёных..., не ростовщиков»), гражданства («не иноверных и не иностранных) ${ }^{15}$ и тому подобное.

Практически, одно из главных положений магдебургского права о годовом сроке пребывания в составе совета в украинских городах не соблюдалось. На должности городских правительственных чиновников попадали самые богатые жители, поэтому в составе совета были представители одних и тех же богатых семей в течение десятков лет. Злоупотребления властью в виде различных нарушений, притеснений и введения ограничений вызывали возмущение со стороны мещан и часто приводили к вооружённым столкновениям и восстаниям против старост и воевод (например, в Черкассах и Каневе в 1536 году, в Виннице и Брацлаве в 1541 году). В таких случаях, в отдельных городах создавались учреждения с контрольными функциями. Например, согласно привилегии короля Стефана

\footnotetext{
${ }^{14}$ Грушевський М. Історія України-Русі: в 11 т. / М. Грушевський. -К.: Наукова думка, 1991. - Т. 5. - С.232.

${ }^{15}$ Дядиченко В. А. Нариси суспільно-політичного устрою Лівобережної України кінця XVII - початку XVIII ст. - К.: вид-во Академії наук Української РСР, 1959. - С. 284.
} 
Батория в 1577 г. во Львове была образованна «коллегия 40 мужей», куда входили наполовину купцы и ремесленники, которых избирали пожизненно. Без её согласия магистрат не имел права проводить какие-либо операции с налогами и расходами.

В начале введения норм магдебургского права ими могли пользоваться только римо-католики, поскольку украинское православное население было отстранено от участия в органах самоуправления городов ${ }^{16}$. Во Львове, Дрогобыче, Перемышле, Каменке и других городах православные украинцы должны были проживать только в одной части города, все мещане-украинцы не имели права участвовать в жизни города по магдебургскому праву. Обращение львовских мещан с жалобой на национальные и религиозные гонения к королю Сигизмунду этого положения вещей не изменило, королевская грамота оставила все предыдущие притеснения украинского населения в силе. В то же время, были иные прецеденты, в частности в Киеве в 1506 г., когда киевские мещане добились отмены штрафа за зажигание ночью свеч.

В начале XIX ст. магдебургское право практически прекратило своё существование. Однако, внося определённые черты западноевропейского городского уклада в организацию самоуправления украинских городов, данное право стало одним из важных факторов сближения Украины с Западной Европой.

\section{5. ВЫВОДЫ}

Ретроспективный анализ показывает, что институт участия членов территориальной общины в решении вопросов местного значения представляет собой определённую систему, являющуюся совокупностью организационных форм и институтов прямого самоуправления, с помощью которых реализуются принципы и функции местного самоуправления. Такая деятельность должна быть организационно обеспечена комплексом методов и мер касательно взаимодействия членов территориальной общины между собой, а также с органами местного самоуправления и местными органами исполнительной власти в процессе решения вопросов местного значения. Кроме того, такое участие возможно при условии нормативного закрепления чётко очерченных организационных форм на законодательном уровне, наделения местных органов власти соответствующими полномочиями относительно привлечения населения к непосредственному участию в процессах местной демократии.

\section{ЛИТЕРАТУРА}

1. Владимирский-Буданов М. Ф. Обзор истории русского права / М. В. ВладимирскийБуданов. - Ростов-на-Дону : Феникс, 1995. - 639 с.

2. Грушевський М. Історія України-Русі : в 11 т. / М. Грушевський. - К. : Наукова думка, 1991. - T. 3. $-592 \mathrm{c}$.

3. Грушевський М. Історія України-Русі : в 11 т. / М. Грушевський. - К. : Наукова думка, 1991. - Т. 5. - 704 c.

4. Дядиченко В. А. Нариси суспільно-політичного устрою Лівобережної України кінця XVII - початку XVIII ст. - К. : вид-во Академії наук Української РСР, 1959. - 532 с.

5. Заборова Е. Н. Участие граждан в управлении городом / Е. Н. Заборова // Социс. - 2002. № 2 . - C. $23-30$.

\footnotetext{
${ }^{16}$ Грушевський М. Історія України-Русі: в 11 т. / М. Грушевський. -К.: Наукова думка, 1991. - Т. 5. - С.238.
} 
6. Кобилецький М. Магдебурзьке право у селах Галичини // Право України. - 2003. - № 8 . - C. $120-124$.

7. Коваленко Н. Е. Местное самоуправление как форма демократии : учеб. пособие / Н. Е. Коваленко. - СПб. : изд-во СПбГУЭФ, 2008. - 296 с.

8. Конституція України : прийнята на п’ятій сесії Верховної Ради України 28 черв. 1996 р. - Режим доступу : http://zakon4.rada.gov.ua/laws/show/254\%D0\%BA/96$\% \mathrm{D} 0 \% \mathrm{~B} 2 \% \mathrm{D} 1 \% 80$.

9. Про місцеве самоврядування в Україні : закон України від 21 трав. 1997 р. № 280/97-ВР. - Режим доступу : http://zakon2.rada.gov.ua/laws/show/280/97-\%D0\%B2\%D1\%80.

10. Тисяча років української сvспільно-політичної дvмки ; у 9 т. Т. 1 / упоряд. О. Сліпушко ; редкол. Т. Гунчак [та ін.]. - К. : Дніпро, 2001. - 632 с.

11. Чубатий М. Огляд історії українського права. Історія джерел та державного права : у 2 ч. Ч. 1 - Мюнхен : [б.в.], 1947. - 88 с.

12. Яремчук В. Бондарчук Я. Магдебурзьке право в Острозі: європейські традиції в українському. - Режим доступу : http://www.day.kiev.ua/27245/. - Назва з екрану.

\section{DEVELOPMENT OF THE POPULATION PARTICIPATION FORMS IN DECISION MAKING ISSUES OF THE LOCAL CHARACTER: RETROSPECTIVE ANALYSIS}

The article deals with the analysis of modern and formed earlier tendencies as to population participation in decision making issues of the local character. The essence and peculiarities of the territorial community as a subject of local self-government in accordance with Ukrainian legislation are considered, the main substantive aspects of local self-government in relation to this study are distinguished. The analy sis of the evolution of the social transformations at the local government level allows to make conclusions that the ideas and practice of self-government occurred in ancient history (before statehood), the predominant forms of which were the people's assembly and the councils of elders, which received the status of the permanent government bodies. The peculiarities of the Veche (popular assembly) democracy in Ukraine are considered. The peculiarities of the convocation, holding Veche and decision-making are shown. The reasons for the rapid spread of the Magdeburg Law in the territory of Ukraine are distinguished. The chronological analy sis of the Magdeburg Law, which allowed the Ukrainian cities to identify three categories of such cities, as well as separate cities depending on their status, is made. The peculiarities of urban selfgovernment on the Magdeburg Law are represented. The analysis, made in the article, allows to conclude of the formation of the institute community members' participation in the structure of local self-government in decision making of issues of local significance as a system, which is a combination of organizational forms and institutions of direct selfgovernment that help implement the principles and functions of local self-government.

Keywords: local self-government, historical analysis, power, administration organs, the Veche, the Magdeburg law, the participation of inhabitants.

\section{DOI: 10.7862/rz.2014.mmr.35}

Tekst złożono w redakcji: sierpień 2014

Przyjęto do druku: wrzesien 2014 